\title{
Dolomitization in the Carboniferous Limestone of the Midlands.
}

\author{
By L. M. Parsons, M.Sc., D.I.C., F.G.S. \\ (WITH PLATE VI.) \\ (Concluded from $p$. 63.)
}

IV. The $D_{1}$ Dolomitic Limestones of Gratton and Long Dale.

The middle portion of the $\mathrm{D}_{1}$ beds seen in the Gratton Dale section consists of about 630 feet of dark dolomitic limestones, which appear to be confined to a definite horizon in the sequence. The impression one at first receives is that here are definitely bedded dolomites probably of contemporaneous origin, and this material has already been referred to as a thick bed of dolomite. ${ }^{1}$ Working

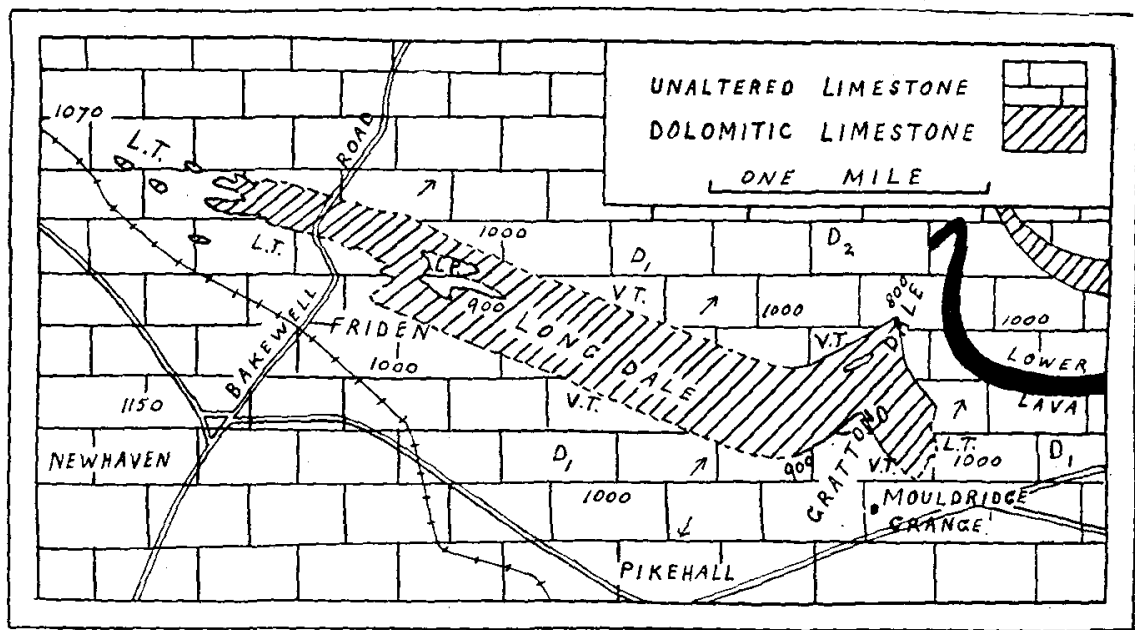

FIG. 3.-Map illustrating dolomitization in Gratton Dale and Long Dale.

northwards down the dale, i.e. ascending the sequence, one finds that the vertical passage from normal limestone into dolomitic material above is everywhere obscured. Similarly the upper limit of the dolomitized beds is covered, so that it is impossible to say whether the metasomatism abruptly ceases with a certain bed or dies out gradually in the higher strata. In the affected part of the sequence the dolomitization appears persistent in Gratton Dale, and at a few places only have I found lateral transitions, one or two examples on either side of the dale. The most marked transition is on the western side, towards the upper part of the altered material. Here light-coloured limestones are seen to pass laterally within a few yards into darker dolomitic material, with which it contrasts. Careful examination shows that these limestones on both sides

1 Dr. H. H. Bemrose, Proc. Geol. Assoc., vol. xxvi, 1915. 
of the Dale are really transitions, and are not interbedded with dolomite, a matter of considerable significance. North-westwards the dolomitization extends for some distance up Long Dale which joins Gratton Dale at right angles.

Throughout Long Dale, which extends parallel with the strike, I have been unable to see any vertical junction between the limestones below and the dolomite above. The vertical change, however, must be fairly abrupt, since for some distance the beds on the northern side are dolomitic while those on the southern side are normal limestones. The actual lower boundary of the metasomatism here lies under the grass-grown bed of the valley. About a mile up Long Dale the valley swerves a little northwards, and the dolomitization is then seen on both sides, indicating that the metasomatism definitely persists along certain beds since the dip of the strata remains the same. Westwards, as Friden is approached, lumps of limestone and dolomite are found mixed in scree material; while still further the dolomitization rapidly becomes less persistent, and good examples of transitions into limestone occur on both sides of the valley. The actual passages from dolomite into limestone are seen to be abrupt. Kernels of limestone, often several feet in width, occur surrounded by dolomitic material. Before the Bakewell road is reached the lower beds have all become normal limestones, and beyond this road the upper dolomitized beds become patchy, and eventually kernels of dolomite in limestone and larger isolated masses, as at Parsley Hay, are all that appears to represent the massive dolomites of Gratton, less than 3 miles distant. Westwards, the field evidences are quite definitely in favour of subsequent dolomitization. Eastwards the matter is less satisfactory. The hilltops above Gratton Dale, a little east of Mouldridge Grange, are overgrown, and I have been unable to trace the dolomitization further. This part of the sequence could, of course, be faulted out, but there is no evidence of this.

The whole of the dolomitized beds pass more or less abruptly into limestone in an easterly direction, and this abrupt passage has its parallel in the sudden transition of Harborough dolomite into the limestone of Middleton Moor, described in the next section. An important feature that must not be overlooked is the fact that in these $D_{1}$ beds the dolomitization is extensive and persistent only in the valleys. Eastwards and westwards where the dales give place to higher ground the metasomatism dies out. This is the converse of the dolomitization on the heights near Matlock.

In their structural and mineralogical features the $D_{1}$ dolomitic limestones of Gratton resemble, in many ways, the material of Winster. Thus considerable obliteration of bedding planes has occurred; vesicular weathering is a prenounced feature, and pseudo-brecciation is absent. On the other hand, there are wellmarked differences between the materials of the two horizons. That at Long Dale is frequently exceptionally coarse in texture; 
cavities and vesicular structures are often on a more pronounced scale, and the material being of $D_{1}$ age is comparatively unfossiliferous.

Microscopic sections typically exhibit grains and crystals generally rather allotriomorphic and of varying size, mixed with residual calcite. Generally the grain is much coarser than that of the Winster or Matlock material, typical dimensions being a minimum diameter of $.09 \mathrm{~mm}$. and a maximum diameter of $\cdot 9 \mathrm{~mm}$, a common size being $\cdot 4 \mathrm{~mm}$. A certain amount of limonite is interstitial, but I have not found any zonal growths of iron oxide. Chert is absent from this part of the sequence. There are no selective phenomena.

Thin sections of the transition limestones show that the original material, if similar, consisted of fine-grained foraminiferal limestone (see Pl. VI, Fig. 1), containing a moderate amount of recrystallized calcite, though the recrystallization might have occurred at a later date. I have not found alternating zonal growths of calcite and dolomite suggesting that calcification and dolomitization may have occurred simultaneously. Analyses show that the bulk of the altered material consists of dolomitic limestone having on an average about 15 per cent of magnesium carbonate, though sometimes the proportion is as low as 8 or 9 per cent. Specific gravity and porosity also vary a good deal, many of the vesicular varieties having a porosity as high as 12 or 13 per cent. Considerable leaching must have occurred, though it must be remembered that shrinkage due to molecular change during metasomatism helps in the production of vesicular structures.

The evidences outlined above amply justify the conclusion that the metasomatism is of subsequent origin and produced by magnesian ground waters, but it is difficult to say at what period or periods the alteration took place and in precisely what manner it was brought about. The dolomitization being persistent only in the valleys might suggest that magnesian waters formerly occupying the dales may have reacted only with certain beds on account of some inherent quality rendering those particular beds susceptible to alteration. This is merely a suggestion, and more definite evidence is necessary before it can be accepted as a proved explanation of the dolomitization. The $D_{1}$ beds of Gratton prove quite conclusively that subsequent dolomitization can affect certain beds and leave others below and above unaltered. Such differential subsequent dolomitization being possibie, caution is necessary with regard to conclusions drawn from apparent interbedding of limestone and dolomite seen in small exposures or restricted areas.

\section{The Dolomites between Parwich Moor and Wirksworth.}

South of Grange Mill highly dolomitic material is extensively developed in two areas, which appear to have formed originally one large outcrop. The Brassington strike fault has let down the western part of the dolomitized mass, the two portions being 
Dolomitization in the Carboniferous Limestone. 107

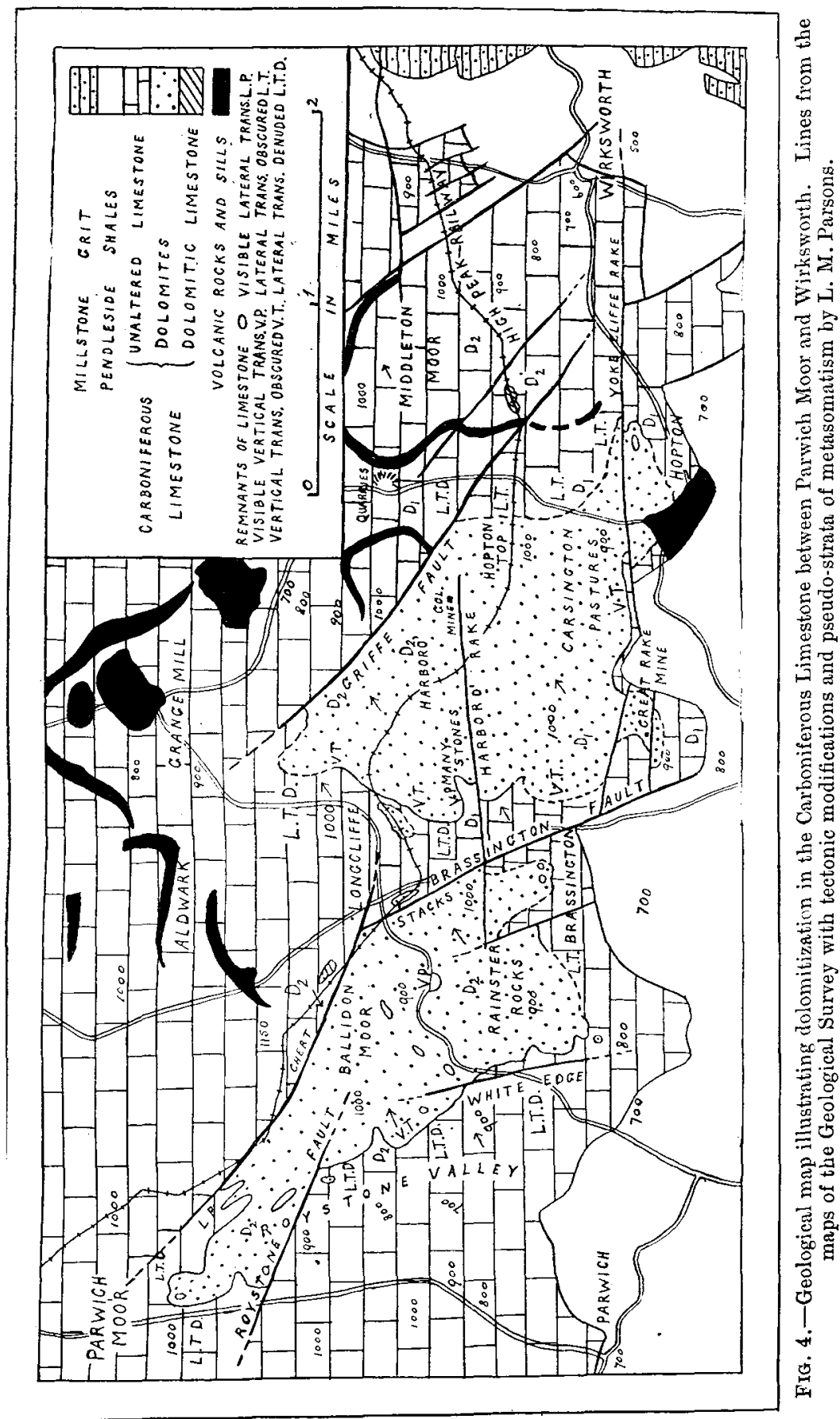


separated by a narrow belt composed of unaltered limestones of a lower horizon in $\mathrm{D}_{1}$.

The metasomatism reaches its culmination in the terraced mass known as Harborough Rocks. In this region the dolomitization appears to be characteristic of a definite part of the sequence and has been described as such in one of the earlier Survey Memoirs. ${ }^{1}$

In a later Survey Memoir the opinion is expressed that the dolomitization is not confined to beds of a particular horizon. ${ }^{2}$

Although the dolomitic material of this district exhibits many inherent features similar to those of the rocks of Winster and Matlock, description in a separate section of the paper is justified mainly by differences in horizon and relations between tectonics and field relations.

\section{Finld Relations.}

Boundaries up and down the sequence.-West of Ballidon Moor, and, again, in the country east of Brassington, where the apparent base of the dolomitic material is brought to the surface by the general dip, there appears to be a sharp line of division between the limestone below and dolomite above. The dolomitization at any particular part of the area so obviously follows the bedding and dip, and is so consistently modified by faulting, that conclusions formed from these prevalent features alone would be decidedly in favour of either primary precipitation or contemporaneous alteration. Whatever may be the origin of the metasomatism, there is no doubt that any part of the field showing Iimestone below and dolomite above exhibits a definite lowest "bed" of dolomite which may be conveniently termed the "basal dolomite". Whether the basal dolomite of one locality is on the same horizon as the basal dolomite of any other locality or occurs at a different horizon, is a question that must be settled by reference to the faunal characters of the lowest dolomite itself and of the limestone immediately below.

At Hopton, Carsington, and south-east of Brassington, the basal dolomite is in the $D_{1}$ part of the sequence and a similar horizon is found in the lowest dolomite near Manystones Quarry, west of Harborough.

In the vicinity of the Griffe Walk, further north, however, the basal dolomite appears to be in $\mathrm{D}_{2}$ beds. Consequently there is, here, a change in horizon and a fairly steep horizon gradient. In the dolomitic mass faulted down west of Longcliffe, the basal dolomite appears to be mainly in $D_{2}$.

Horizon changes are generally so gradual that they are imperceptible at any restricted portion of the field. It is clear that the $\mathrm{D}_{1}$ portion of the Harborough dolomite has passed laterally into

1 North Derbyshire, 1887, p. 24.

2 The Geology of the Northern Part of the Derbyshire Coalfield and Bordering Tracts, 1913. 
limestone between Manystones and the region around the Rainster Rocks, less than 1 mile distant.

Faunal evidences prove that the bottom of the basal dolomite in the district as a whole is not a true stratigraphical plane of separation.

Evidences obtained from exposed vertical transitions also tell against the theory of contemporaneous origin. In a field west of Manystones, several yards of the "basal dolomite" are seen resting on unaltered limestone. The junction, though sharply marked, does not conform accurately to the bedding. At certain places irregular metasomatic patches invade the limestone below. Thin sections of the limestone in contact with dolomite do not show any dolomite rhombohedra, hence the metasomatism, though irregular, ceases abruptly.

The small exposure near the roadway north of the Rainster Rocks shows a few feet of dolomite sharply separated from limestone below. Thin sections of the limestone in contact with dolomite show that here dolomitization, imperceptible megascopically, has affected the limestone on a minute scale. Well-marked dolomite rhombohedra occur in both organisms and matrix, the latter being partly recrystallized (Pl. 2, Fig. 2). The degree of magnesiation in the limestone immediately below the basal dolomite is thus varied in the area, and ranges from megascopically apparent epiphyses to the entire absence of magnesium carbonate as shown by microscopical sections and chemical analyses. In the workings of the Golconda Mine ${ }^{1}$ the basal dolomite is persistently separated from the limestone below by a sharp boundary which conforms to the bedding.

A striking feature which lessens the value of evidence from the vertical passage seen in these workings is the occurrence of a "wayboard " of clay separating the dolomite and limestone. The inference that the limestone below may have been protected by this clay from metasomatism appears legitimate. In a cutting at Longcliffe station and in quarries near Longcliffe pseudo-interbedding effects similar to those of the exposure near Manystones are seen.

The higher vertical transition of the upper dolomites into limestone is not seen anywhere in the whole district between Roystone and Wirksworth. It is to be regretted that the passage material has either been removed by denudation as at Harborough and Rainster, or has been let down by faulting as at Griffe Wood and north-west of Longcliffe. Towards Wirksworth, where the sequence ascends into higher $\mathrm{D}_{2}$, lateral transition has occurred.

Lateral Boundaries.-The eastern boundary of the Harborough and Carsington dolomitic mass is partly faulted and partly of the nature of abrupt lateral transition into limestone. In the region of the Griffe Wood a sharp straight line with dolomite on one side and limestone on the other marks the position of the Griffe Fault. I have not found any traces of magnesiation in the limestone thus

1 For facilities to examine these workings $\mathrm{I}$ am indebted to the courtesy of the manager, Mr. E. Weightman. 
brought abruptly against dolomite. Thin sections show organic structures in a matrix mostly non-recrystallized, and no rhombohedra are present. It is quite clear from field and petrological evidences that this fault has no relation to the origin of the metasomatism. Apart from all other evidences, the moderate throw of this fault as shown by the presence of a $D_{2}$ fauna in the higher Harborough beds is fatal to any conception that the massive dolomites of Harborough and Rainster might be a continuation of the thick middle $D_{1}$ dolomitic series of Gratton Dale, described in Section IV. East of the Hopton roadway, the Hoptonwood Quarries exhibit a considerable vertical section embracing a large portion of the $D_{1}$ sequence below the lava while lower $D_{2}$ beds above the lava are seen on Middleton Moor. The shaft of the old Snake Mine pierces other beds lower in $D_{1}$, and a table of the strata seen there is given in one of the Survey Memoirs. ${ }^{1}$ No dolomitization whatever is found in any of the material seen in the Snake Mine, in the Hoptonwood Quarries, or on Middleton Moor. It is evident that the dolomitized beds around Harborough have all passed more or less abruptly into normal limestones somewhere between the position of the Griffe Fault and the Hoptonwood Quarries, a distance less than three-quarters of a mile. Near the High Peak Railway, and further southwards visible exposures indicate that the dolomitized $\mathrm{D}_{1}$ beds here pass rapidly into limestone though the actual lateral contacts are obscured. Along the southern boundary from Hopton to the Great Rake Mine, the dolomite and the underlying limestones have been faulted down to the south. In the absence of borings it is impossible to say how far southwards the dolomitization extends. The faults near the Great Rake Mine have produced lateral shifting of the dolomite pseudo-strata. The junction of dolomite and limestone is again quite distinct and along straight lines. The western boundary of the dolomite from Griffe Walk to the southern extremity near the Great Rake is a weathered termination along the strike, the pseudo-strata being modified at one or two places by dip faulting.

In the mass west of the Brassington Fault, certain dolomitized $D_{2}$ beds extend westwards for about 2 miles. In the vicinity of the Rainster Rocks another strike fault is indicated by a straight line of demarkation between dolomite on the west and limestone on the east, while the Harborough Rake produces a well-marked lateral shift in the dolomitic material. Behind Brassington Church are several remnants of limestone in dolomite. Other large remnants of limestone occur west of the Rainster Rocks, and indicate transition in some of the lower dolomites. Owing to these transitions and the White Edge fault, the dolomitization in the Roystone Valley is restricted to the hill-tops along the eastern side, until an extensive dip fault lets the material down, the dolomite then occurring on both sides of the valley. The Roystone fault is one of the most clearly marked in the

1 North Derbyshire, 1887. 
district, and shows apparently thick-bedded dolomite against thinbedded white limestones.

It is evident that the transition material formerly on the western hill-tops has been denuded. South of the fault dolomitic stacks surrounded by limestone occur on the eastern side of the valley. A little north of the fault lateral transition of some of the dolomitized beds gives the appearance of interbedding of dolomite and limestone. Still higher up the valley more lateral transitions occur on the eastern side, and extensive dolomitization finally dies out just beyond the Roystone Rocks near the roadway from Parwich to Pike Hall.

The northern boundary of the Rainster mass is certainly faulted ; limestones with chert are brought against dolomite without chert, and the direction of the dip is different.

In the whole district from Hopton to Roystone the persistent modification of the dolomitic pseudo-strata by the faults is a feature of considerable significance. If the dolomitization were of the type in which faulting had been a factor, it is inconceivable that such a large majority of the faults in the district would show limestones one side of each fault plane and dolomite on the other. It is quite definite that the dolomitization must have occurred prior to the dislocations and is independent of them. The metasomatism is of a subsequent type, but of great antiquity, and probably occurred soon after the Carboniferous Limestone was formed.

With regard to evidences connected with the relation between faulting and dolomitization, certain features may be summarized briefly :--

In the case of primary, or contemporaneous, or subsequent dolomitization which occurred prior to faulting :-

(1) If the throw of a fault is sufficient a "bed" of dolomite is usually against a bed of limestone, and the faulted junction is a sharp line of demarkation.

(2) With thick dolomites a fault of small throw may produce dolomite against dolomite.

(3) The outcrops or pseudo-strata are affected by faulting in the usual ways.

(4) Megascopic crystals of dolomite are not usually found in fault planes and cavities. Should such crystals occur, complex or compound dolomitization may be indicated.

In cases of subsequent dolomitization occurring after faulting, particularly alteration of the "vein" type :-

(1) The beds on both sides of the fault are usually affected though those on one side may be more affected than those on the other owing to differences of texture, etc. The line of fault is typically not a sharp line of demarkation.

(2) Dolomitization is more marked in the immediate vicinity of the fault. 
(3) The outcrop does not resemble the outcrop of a bedded deposit.

(4) Crystals of dolomite frequently occur in the fault plane and in adjacent cavities.

\section{Inherent Structurat and Mineralogical Features.}

Many of the structural characters of the material between Hopton and Roystone are very similar to those of the dolomitic limestones around Winster, hence it will suffice if features common to the material of both districts are enumerated and a few notes added.

The common features include :-

Megascopic.-Welding of beds and consequent obliteration of bedding, enlargement of joints, shrinkage, dolomitic stacks and vesicular (differential) weathering.

Microscopic.-The general tendency to allotriomorphism and considerable variation in size of grain (see PI. VI, Fig. 3), dusky inclusions, interstitial limonite frequently, zonal inclusions of limonite occasionally, and inconclusive " selective" features. (See Pl. VI, Fig. 4.)

On the other hand, the Harborough and Rainster material differs from that of Winster in containing no chert, there is no pseudobrecciation at all, and in the absence of the lava which dies out near the Griffe Fault, there is no question of metamorphic effects. Obliteration of bedding is prevalent throughout the whole area, and is nowhere better marked than at the Roystone fault. Stacks and pinnacles of dolomite are more extensively developed than in the Winster area, the Roystone Rocks and Rainster Rocks exhibiting this feature in a striking manner. Vesicular weathering is almost universal.

Variation in size of grain is indicated by the following figures obtained from typical sections :-

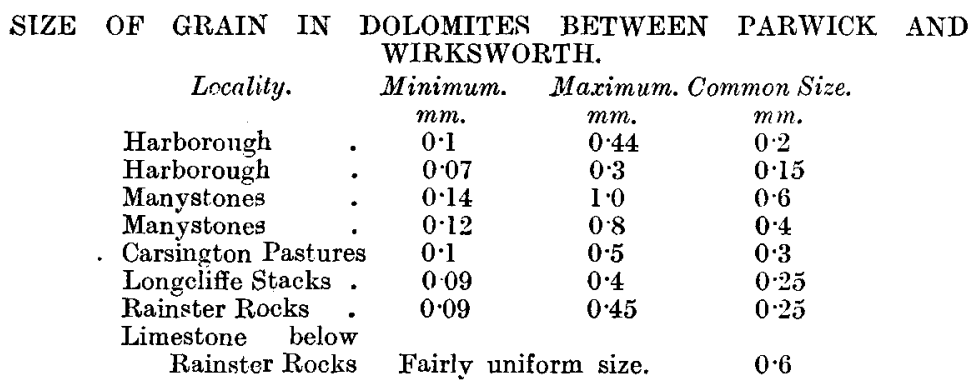

The large idiomorphic crystals in the limestone immediately below the " basal " dolomite of the Rainster Rocks contrast strongly with the allotriomorphic grains in typical material of Harborough, Carsington Pastures, etc. The same mode of magnesiation appears to have produced contrasting results which must have been 
determined by other inherent factors as suggested above (cf. Figs. 2 and $3, \mathrm{Pl}$. VI).

Zonal inclusions of limonite are uncommon, but some of the Harborough dolomite exhibits features very similar to those of the Complex-subsequent $\mathrm{D}_{2}$ dolomitic material of Gratton Dale. Fig. 4, Pl. VI shows coral structures (Lithostrotion) replaced by dolomite free from zonal limonite inclusions, but the matrix mostly contains dense zonal growths of limonite. (Compare with Fig. 3, Pl. IV.) Recrystallized calcite occurs within the spaces between the coral septa. Dolomitization at two different periods is indicated. "Selective" features are varied and contradictory. In examples like that just mentioned, both coral and matrix are almost completely dolomitized, but with dolomite of different types, presumably of different period. In other cases corals are partly in calcite and partly in dolomite, while the matrix is mostly dolomitized. The limestone below the Rainster Rocks shows rhombohedra scattered indiscriminately through both matrix and organic structures.

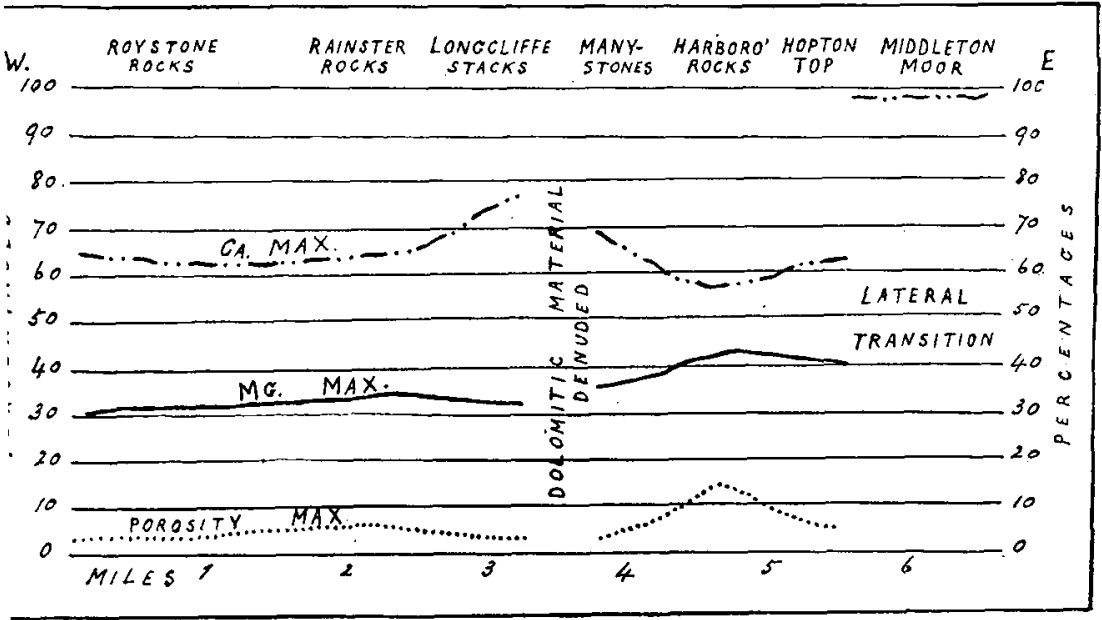

FIG. 5.-Graphs illustrating variation in chemical composition and porosity of the dolomites between Parwich Moor and Wirksworth.

The Presence and Conprtion of Fossirs.

The general condition of organic remains, and the varied nature of "selective" phenomena so closely agrees with the corresponding features found in the material of Winster and Matlock that the remarks made in Section III equally apply to the material of the Harborough and Rainster dolomites.

\section{Chemical Composition and Porosity.}

Chemically, the bulk of the material between Parwich and Wirksworth resembles a true dolomite in having a high proportion of magnesium. Numerous analyses of typical specimens from various 
parts of the district show that the dolomitization has been most intense in the immediate neighbourhood of the Harborough Rocks, and that outwards from this centre there is a general fall in the proportion of magnesium southwards towards Carsington and Hopton and westwards towards Roystone.

The dolomitic gradient is, on the whole, moderate, and only at one part of the area, near Longcliffe, have I found a sudden drop in the proportion of magnesium similar to that which occurs in the material near the Wyn Tor, described previously.

In the district as a whole, the chemical variation is not marked in a vertical direction, the lower beds having much the same composition as higher strata at the same locality. The metasomatism ends abruptly at the junction of the "basal dolomite" and the underlying limestones, analyses of the latter showing no magnesium except in the case of the material under the basal dolomite of the Rainster Rocks, which yielded less than 8 per cent of magnesium.

The figures obtained by dividing the percentage of magnesium carbonate by the porosity do not give a constant, and indicate that prior to leaching the dolomitization was not uniform.

TABLE ILLUSTRATING VARIATION IN CHEMICAL COMPOSITION, SPECIFIC GRAVITY, AND POROSITY OF DOLOMITES BETWEEN PARWICH MOOR ANI WIRKSWORTH. ${ }^{1}$

\begin{tabular}{|c|c|c|c|c|c|c|c|c|}
\hline Locality. & $\mathrm{CaCO}_{3} \cdot$ & $\mathrm{MgCO}_{3}$. & Fe Comp. & Residue. & S.G. & $\begin{array}{l}\text { S.G. of } \\
\text { Powder. }\end{array}$ & Porosity. & $\begin{array}{l}\text { Per cent } \\
\text { of McCO } \\
\text { Porosity }\end{array}$ \\
\hline Hopton & $62 \cdot 2$ & $34 \cdot 3$ & $1 \cdot 1$ & $2 \cdot 4$ & $2 \cdot 46$ & $2 \cdot 59$ & $5 \cdot 0$ & 6.8 \\
\hline Hopton & $56 \cdot 8$ & $40 \cdot 5$ & 0.9 & 1.8 & $2 \cdot 51$ & $2 \cdot 67$ & $5 \cdot 9$ & $7 \cdot 0$ \\
\hline Harborough & $46 \cdot 4$ & $43 \cdot 6$ & $3 \cdot 4$ & $6 \cdot 6$ & $2 \cdot 22$ & $2 \cdot 61$ & $14 \cdot 9$ & $3 \cdot 0$ \\
\hline Harborough & $57 \cdot 1$ & $36 \cdot 9$ & $1 \cdot 3$ & $4 \cdot 8$ & $2 \cdot 48$ & 264 & $6 \cdot 1$ & $6 \cdot 0$ \\
\hline Nanystones & $60 \cdot \overline{0}$ & $35 \cdot 7$ & $1 \cdot 1$ & $1 \cdot 7$ & $2 \cdot 53$ & $2 \cdot 63$ & $3 \cdot 8$ & $9 \cdot 6$ \\
\hline Manystones . & $69 \cdot 3$ & $27 \cdot \tilde{0}$ & 0.9 & $2 \cdot 3$ & 251 & 258 & $2 \cdot 7$ & $10 \cdot 2$ \\
\hline Carsington Pastures & $58 \cdot 7$ & $38 \cdot 4$ & $1 \cdot 0$ & $1 \cdot 9$ & $2 \cdot \tilde{5} 5$ & $2 \cdot 69$ & $5 \cdot 2$ & $7 \cdot 4$ \\
\hline Carsington Pastures & $62 \cdot 3$ & $35 \cdot 9$ & $0 \cdot 7$ & $1 \cdot 1$ & $2 \cdot 49$ & $2 \cdot 63$ & $5 \cdot 3$ & $6 \cdot 7$ \\
\hline Longcliffe Stacks & $64 \cdot 9$ & $32 \cdot 6$ & $0 \cdot 7$ & 1.8 & $2 \cdot 5.2$ & $2 \cdot 64$ & $4 \cdot 1$ & $7 \cdot 9$ \\
\hline Longcliffe Stacks & 765 & $20 \cdot 7$ & 06 & $2 \cdot 2$ & $2 \cdot 52$ & $2 \cdot 61$ & $3 \cdot 4$ & $6 \cdot 0$ \\
\hline Rainster Rocks . & $63 \cdot I$ & $33 \cdot 8$ & $I \cdot 2$ & 199 & $2 \cdot 54$ & $2 \cdot 69$ & $6 \cdot 0$ & $5 \cdot 5$ \\
\hline Roystone Valley & $65 \cdot 4$ & $3] \cdot 9$ & $1 \cdot 1$ & $1 \cdot 6$ & 2.55 & $2 \cdot 71$ & $5 \div$ & $5 \cdot 6$ \\
\hline
\end{tabular}

Field relations, certain inherent structures, and chemical composition supply a large balance of evidence indicating that the dolomitization between Parwich and Wirksworth is of a subsequent kind produced by the influence of ground waters. The fact that in the whole of Central Derbyshire the maximum magnesiation is towards the east gives considerable support to the theory of Permian influence. While the magnesian material of the Winster, Matlock, and Harborough districts may have had a common source of origin, there is no proof that the metasomatism in any one of these districts was simultaneous with that in any other.

${ }^{1}$ For considerable help in the chemical part of the work $I$ am indebted to Messrs. A. G. Brighton, C. Jenkins, and H. D. Thomas. 


\section{VI.-Summary of Conclusions and Comparison with the LeICESTERSHIRE DoLomites.}

The Carboniferous Limestone of the Midlands exhibits two contrasting types of dolomitization :-

(1) Wholly subsequent in the main limestone mass in Central Derbyshire, and

(2) Almost wholly contemporaneous in the marginal deposits north of the Leicestershire Coalfield.

In neither case is there any extensive development of typical "vein" dolomitization.

In Central Derbyshire :-

(1) Magnesian ground waters appear to have been the agent of metasomatism, but the source of the magnesium is not definitely indicated.

(2) The dolomitization is of more than one period, as shown by certain complex-subsequent types, and as suggested by the relation between the metasomatism and the topography. There is little to indicate the period at which dolomitization took place in the Winster, Gratton Dale, and Matlock districts, but in the case of the widespread alteration in the Harborough area further south, the dolomitization must have occurred prior to the extensive faulting there seen.

(3) It is shown that subsequent dolomitization is capable of affecting certain beds, while others above and below may be left unaffected, hence apparent interbedding is not necessarily a proof of contemporaneous alteration. Different horizons are affected in different parts of the area, the affected horizons in the district as a whole being Middle $\mathrm{D}_{1}$, top of $\mathrm{D}_{1}$, lower $\mathrm{D}_{2}$, and locally near Winster, Upper $\mathrm{D}_{2}$; Upper $\mathrm{D}_{1}$ beds are affected only around Harborough. Within these portions of the sequence the metasomatism varies horizon, and the surface areas of dolomitization are pseudo-strata.

(4) Extensive dolomitization in Middle $D_{1}$ beds is generally restricted to the valleys of Gratton Dale and Long Dale, but that on higher horizons is mostly confined to hill-tops and moors.

(5) On all horizons, lateral transitions into limestone are abrupt, and the transition limestones exhibit feeble or only moderate calcitic recrystallization.

(6) On all horizons the dolomitic material exhibits a general tendency to allotriomorphism, and thus contrasts strongly with some subsequent dolomites of other districts.

(7) Dolomitization has generally produced an increase in size of grain, but in spite of this increase the size of grains and crystals are frequently smaller than those of some contemporaneous dolomites of other areas. Neither allotriomorphism nor size of grain can be accepted as unimpeachable evidence of the mode of magnesiation. Such features appear to be closely related to the original texture and mineralogical constitution of the rock, and to the intensity of the magnesian factor in the agent of metasomatism. 


\section{Dolomitization in the Carboniferous Limestone.}

(8) In this area "selective" features are varied and cannot be accepted as a source of evidence of the mode of magnesiation. In the production of such features, the original constitution of the rock is probably the chief factor.

(9) Chemical composition is varied even within small portions of the affected areas, the dolomitic gradients being in some cases steep, in others more gentle. The intensity of magnesiation is greater in the regions around Harborough and Matlock Bath, the magnesian contents generally decreasing southwards and westwards towards Parwich, and north-westwards towards Gratton.

(10) Porosity is intimately related to dolomitization, the general connexion being that the greater the degree of magnesiation the higher the porosity. Porosity is due to dolomitic reconstitution of the rock and to post-metasomatic leaching. Pronounced vesicular weathering is a feature associated with subsequent dolomitization.

Bordering the Leicestershire Coalfield :-

(1) The bulk of the sequence consists of some 800 feet of wellbedded contemporaneous dolomites without alternation with limestones. The surface areas of dolomitization are not pseudo-strata. These rocks constitute a shallow-water facies formed during longcontinued subsidence.

(2) The horizons affected by this contemporaneous alteration include all of the visible $D_{1}$ beds and nearly all of the $D_{2}-{ }_{3}$ part of the sequence. These dolomites, therefore, are in Central Derbyshire represented by deposits originally normal limestones, some of which have been subsequently dolomitized. How far northwards from Leicestershire the contemporaneous metasomatism extends is not known, the Carboniferous limestone being obscured by Trias.

(3) Lateral transitions into limestone and many other features found in Central Derbyshire are absent.

(4) The dolomitic material on all horizons affected by contemporaneous alteration is generally allotriomorphic and fine grained.

(5) "Selective" features are absent, matrix and organisms including corals being completely dolomitized.

(6) Chemical composition is comparatively uniform, there being slight variation in magnesian contents, but no marked dolomitic gradients similar to those of the Winster or Longcliffe districts.

(7) Porosity is small, evidences of extensive leaching are absent, and there is no vesicular or differential weathering.

(8) A small portion of the sequence towards the top of $\mathrm{D}_{2}-{ }_{3}$ exhibits a variety of types. Some of these beds exhibit contemporaneous alteration, but have been subsequently dolomitized by waters associated with the Trias. Still higher beds showing very incomplete metasomatism and inconclusive "selective" features cannot definitely be assigned to any particular mode of magnesiation. The highest beds, at Ticknall, are composed of completely dolomitized material apparently of contemporaneous origin. 
1
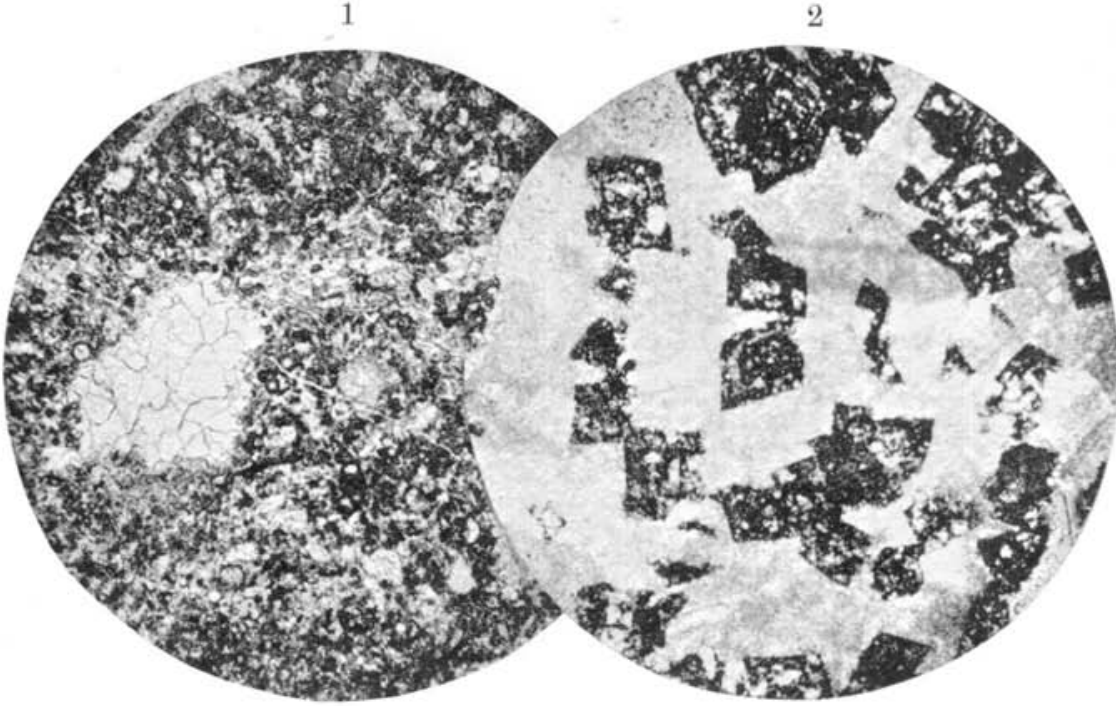

3

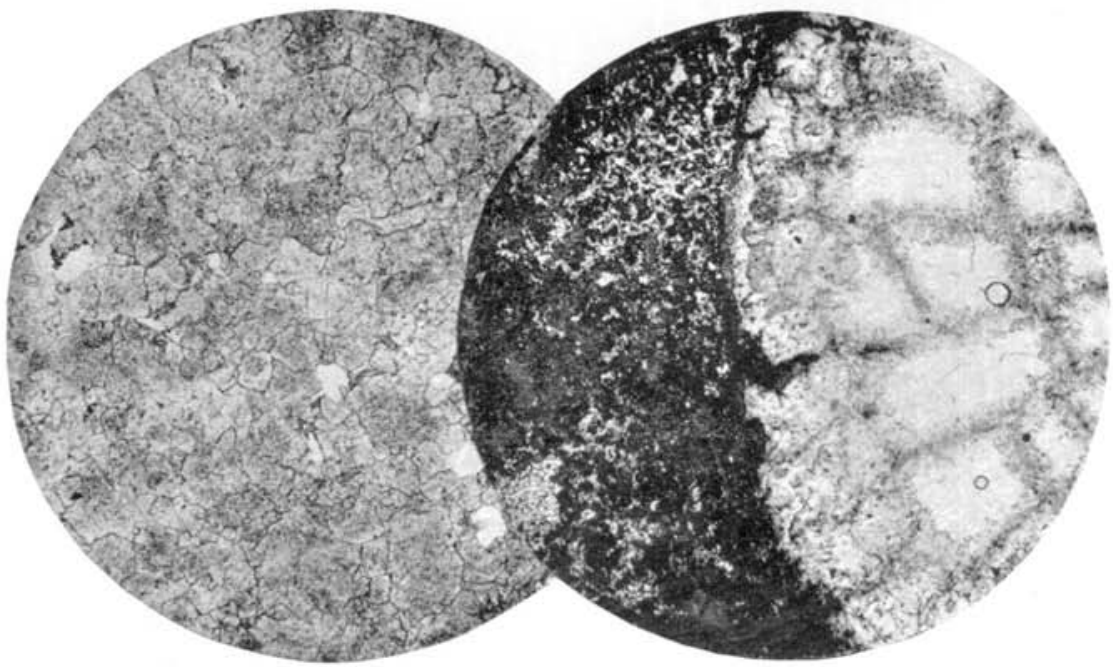

G. S. Sweeting, photomic.

To face p. 11r?

Linestone and Dolonites, Derbyshire. 
I take this opportunity to acknowledge gratefully the financial help afforded by a grant awarded to me by the Government Grant Committee of the Royal Society.

My thanks are also due to those geologists who have kindly assisted me in many ways. To Professor W. W. Watts $I$ am particularly grateful for continual encouragement and advice, for facility to carry out part of the work at the Imperial College, and for his kindness in reading the manuscript.

Dr. T. F. Sibly has been good enough to look over some of my zonal results, and I am indebted to Mr. C. B. Wedd for discussion of the phenomena occurring near Matlock. Dr. A. Holmes and Mr. H. C. Sargent have also helped me with suggestions and criticism. The photomicrographs illustrating this paper are the work of Mr. G. S. Sweeting, and I owe much botb to him and to Mr. E. J. Tallin, who has assisted me with the petrological part of the work.

I am indebted to Mrs. L. M. Parsons for much help with the manuscript, and I acknowledge the companionship of my friend Dr. W. H. Turton, who has frequently accompanied me in the field.

\title{
EXPLANATION OF PLATE VI.
}

FIG.

1.-Transition limestone, $D_{1}$ beds, Gratton Dale. $\times 23$. Recrystallized ealcite is not common, but occurs occasionally in patches as shown.

2.-Limestone immediately below the "basal" dolomite, Rainster Rocks. $x$ 25. Dolomite rhombohedra with included limonite (not zonal) scattered indiscriminately through matrix and organisms.

3.-Typical dolomite of the Harborough district. $\times 23$. Specimen obtained near Manystones Quarry. Rather allotriomorphic and coarse grained.

4.-Coral in dolomite, Harborough Rocks. $\times 23$. Matrix of dolomite having some zonal inclusions of limonite, coral (right) in dolomite free from such inclusions. Recrystallized calcite in internal spaces. (Cf. No. 3, Plate IV.)

\section{The Carboniferous Limestone Series of West Cumberland.}

\section{By Charles Edmonds.}

\author{
(Concluded from p. 83.)
}

\section{Shaliow Water and Lagoon Phases.}

In a series which in no part can be described as other than shallow water there are certain passage-beds, speaking of special and varying conditions of deposition, which must be noted. At the very base of the series dolomite-mudstones with ostracods and calcitemudstones with Spirorbis-like annelids, with thin interbedded shales and limestone-bands with a standard marine fauna, denote quiet lagoon conditions with occasional access to open sea. The whole of the Seventh Limestone with its calcite-mudstones, chinastone-limestones and gasteropod-beds, totalling upwards of 150 feet in places, represents generally shallow-water conditions, but there is a remarkable absence of contemporaneous dolomitization in the 